\title{
ANALYSIS OF DELAY IN EXECUTION OF CONSTRUCTION PROJECTS
}

\author{
P. Muralidhar ${ }^{1}$, Rahul Kumar Jain ${ }^{1}$, B. Srivasta ${ }^{1}$, V. Poorna Chandra Rao ${ }^{1}$ \\ ${ }^{1}$ National Institute of Construction Management and Research (NICMAR), Hyderabad, India. \\ Date received: 8/03/18, Date accepted: 19/04/18 \\ Corresponding Author's Email: pmuralidhar17@gmail.com
}

\begin{abstract}
The construction industry is one of the major sectors that provide important ingredients for the development of country's economy. A survey is conducted to identify the major causes of construction delays, its effects, and minimizing delays in construction projects using relative importance index method. The questionnaire was circulated among various construction companies located in India to find the reasons which are affecting the construction projects in India. The various factors are identified for this purpose and these critical factors are then categorized into owner, contractor, consultant, material, design, labor, equipment and external factors. About fifty six responses are received for the analysis purpose. SPSS software is applied to perform the analysis. The survey is concentrated on the frequency of occurrence of this factors and what is the severity of this factors in the five point scale.
\end{abstract}

Copyright $\odot 2018$ UNIMAS Publisher. This is an open access article distributed under the Creative Commons Attribution-NonCommercial-ShareAlike 4.0 International License which permits unrestricted use, distribution, and reproduction in any medium, provided the original work is properly cited.

Keywords: Construction projects, delays, relative importance index, construction industry, critical factors.

\subsection{INTRODUCTION}

The Construction industry is one of the key economic industry in India and is the main motivating force in Indian national economy. But, it suffers from a number of problems that affect time, cost and quality performances. Successful management of construction projects is based on three major factors i.e. time, cost and quality. Time and cost are the lifelines of any project. The success or failure of any project depends largely on these two factors apart from its quality. These factors are vital, still they are neglected in execution of projects [1]. It has been observed very frequently that most of the projects are closed with time and cost overruns due to various reasons [2]. It's a rare scene in construction industry, that a project is completed well within the estimated budget and time and with desired quality.

"DELAY IS THE ENEMY OF PROGRESS" - Eliot Spitzer. Delay is one of the biggest problems, the construction firms face. Delays can lead to many negative effects such as law suits between owners and contractors, higher project costs, loss of productivity and revenue, and contract termination [3]. The construction companies in many countries around the world experiencing significant delays. However, delay situations are complex in nature because multiple delays can occur concurrently and they can be affected by more than one party or none of the principal parties [4]. One delay may contribute to the formation of other delays. In complex and large projects, delays are analyzed based on the two major parameters i.e. time and cost because recording each activity schedules is difficult [5]. The delay in infrastructure projects affects the economy of the country, so it is important for the projects to be completed within the budgeted cost and time [6].

There are four basic ways to categorize the delays.

a) Critical or Non-Critical

Delays that affect the project completion or in some cases a milestone date are considered as critical delays and delays that do not affect the project completion or a milestone date are considered as noncritical delays $[7,8]$. If these activities are delayed, the project completion date or a milestone later will be delayed.

b) Excusable and Non-Excusable Delays

An excusable delay is a delay that is due to an unforeseeable event beyond the contractor's or the subcontractor's control. Non-excusable delays are events that are within the contractor's control or that are foreseeable [9].

c) Concurrent or Non-Concurrent 


\section{Journal of Civil Engineering, Science and Technology}

Volume 9, Issue 1, April 2018

The concept of concurrent delay has become a very common presentation as part of some analysis of construction delays [10]. The concurrency argument is not just from the standpoint of determining the project's critical delays but from the standpoint of assigning responsibility for damages associated with delays to the critical path.

d) Compensable or Non-Compensable

A compensable delay is a delay where the contractor is entitled to a time extension and to additional compensation. Relating back to the excusable and non-excusable delays, only excusable delays can be compensable. Compensable delays are caused by the owner or the owner's agents [11].

\subsection{LITERATURE REVIEW}

The project study is based on Descriptive Investigation. The sampling method is Simple random sampling. The questionnaire was sent to 120 respondents of construction industry and Feedback is obtained from 70 professionals of construction industry. Out of which it is found that 56 responses are found suitable for the present investigation. Primary data is collected from the sources through questionnaire method [12]. The respondents are mainly the contractors who are involved in execution of construction projects $[13,14]$. The Project involves identification of about 33 causes which are mainly effecting in the delay of construction projects. A questionnaire was developed in order to evaluate the frequency of occurrence, severity and importance of the identified causes. Data was gathered through a survey and analyzed by using frequency; severity and Importance indices, taking in view contractors and ranks are listed for various delays depend on criticality $[15,16]$.

\subsection{QUESTIONNAIRE DESIGN}

Data was gathered through a questionnaire. The questionnaire is divided into three main parts. Part 1 is related to General information about respondent. The contractors were further requested to answer questions pertaining to their experience in the construction industry and their opinions about the percentage average time delay in projects they experienced [17-19].

part 2 and part 3 includes the list of the identified causes of delay in construction project. These causes are classified into nine groups according to the sources of delay. The Groups are as follows.

1. Delay at Project level

2. Delay due to client

3. Delay due to Contractor

4. Delay due to Designer.

5. Delay due to Labor and equipment

6. Delay due to Materials groups

7. Delay due to consultant

8. Delay due to contractual related issue

9. Delay due to External groups

For each factor of cause two questions were asked :

What is the frequency of occurrence for this cause, what is the degree of severity of this cause in project delay

Both frequency of occurrence and severity were categorized as follows: always, very often, often, sometimes and rarely (on 5 to 1 point scale). Similarly, degree of severity was categorized as follows: Extremely, High, Moderate, Low and Significant (on 5 to 1 point scale). The collected data is analyzed through some Statistical Technique and software such as Microsoft Excel, SPSS. 


\section{Journal of Civil Engineering, Science and Technology}

Volume 9, Issue 1, April 2018

\subsection{HYPOTHESIS}

$\mathrm{H}(0)$ There is no significant difference in severity among the identified causes causing delay in Construction project due to the delay group

$\mathrm{H}$ (a) There is a significant difference in severity among the identified causes causing delay in Construction project due to the delay group

$\mathrm{H}(0)$ There is no significant difference in Frequency among the identified causes causing delay in Construction project due to the delay group

$\mathrm{H}$ (b) There is a significant difference in Frequency among the identified causes causing delay in Construction project due to the delay group.

\subsection{METHODOLOGY}

\subsection{DATA VALIDATION - PERFORMANCE OF ANNOVA FOR EACH GROUP}

Analysis of variance (ANOVA) is applied for each group in order to determine the validity of responses for finding out whether there is a significant difference between the various identified causes causing delay in construction projects or not for degree of severity and frequency. ANOVA is applied among the identified 9 group in order to determine the validity of responses by finding out whether there is a significant difference between the various identified groups causing delay in construction Projects or not for degree of Severity and Frequency. ANOVA is applied at 5\% level of significance. Mean of the responses are feed into the SPSS software and results is generated by working with the "Analyze" tool and performing One way ANOVA for degree of Severity and Frequency.

\subsection{RELATIVE IMPORTANCE INDEX}

A formula is used to rank the causes of delay based on frequency of occurrence as identified by the participants as mentioned

$$
\text { Frequency Index } \left.(\text { F.I })=\left(\sum \text { a n }\right) \div \mathrm{N}\right) *(100 \div 5)
$$

Where

a - constant expressing weighting given to each response (ranges from 1 for rarely up to 5 for always),

$\mathrm{n}$ - Frequency of the responses.

$\mathrm{N}$ - total number of responses.

5-Point Likert Scale for Frequency of Occurrence

Always (5) : Generally occurs in all the projects (70\%-100\%).

Very often (4) : Occurs in 5 to 7 projects out of 10 projects $(50 \%-70 \%)$.

Often (3) : Occurs in 3 to 5 projects out of 10 Projects $(30 \%-50 \%)$

Sometimes (2) : Occurs in 1 to 3 projects out of 10 Projects (10\%-30\%).

Rarely (1) : Occurs only 1 time out of 10 projects $(>10 \%)$.

Determination of Severity Index: A formula is used to rank causes of delay based on severity of occurrence as identified by the participants.

$$
\text { Severity Index } \left.(\text { S.I })=\left(\sum \text { an }\right) \div \mathrm{N}\right) *(100 \div 5)
$$

Where

a - constant expressing weighting given to each response (ranges from 1 for Insignificant up to

5 for extremely),

$\mathrm{n}$ - Frequency of the responses. 


\title{
Journal of Civil Engineering, Science and Technology
}

\author{
Volume 9, Issue 1, April 2018
}

$\mathrm{N}$ - total number of responses.

5-Point Likert Scale for Degree Of Severity

Extremely (5) : Greater than $70 \%$ increase in cost and time of project.

High (4) : $: 50 \%$ to $70 \%$ increase in cost and time of project.

Moderate (3) : $30 \%$ to $50 \%$ increase in cost and time of project.

Low (2) : $\quad 10 \%$ to $30 \%$ increase in cost and time of project.

Insignificant (1) : Less than 10\% increase in cost and time of Project

Calculation of Relative Importance Index: The importance index of cause is calculated as a function of both frequency and severity indices, as follow s:

$$
\text { Relative Importance Index }(\text { R.I.I } \%)=(\text { F.I\% } * \text { S.I\% }) \div 100
$$

\subsection{RESULTS AND DISCUSSION}

Based on the ANOVA performed for each group for the degree of severity and frequency, the results were portrayed in Table 1, Table 2, and Table 3 respectively.

Table 1 ANOVA Results of each group for degree of severity

\begin{tabular}{lcccc}
\hline & \multicolumn{2}{l}{ Degree of severity } & & \\
Groups & Fcritical & F & P value & P sign \\
\hline project & 1.58603 & 1.780583 & 0.019796 & 0.05 \\
Owner & 1.477814 & 3.684672 & $1.93 \mathrm{e}-09$ & 0.05 \\
Contractor & 1.488708 & 7.116961 & $1.5 \mathrm{e}-19$ & 0.05 \\
Consultant & 1.58603 & 3.06496 & $2.95 \mathrm{e}-05$ & 0.05 \\
Design & 1.53208 & 5.727786 & $1.21 \mathrm{e}-12$ & 0.05 \\
Material & 1.58603 & 2.699197 & 0.000187 & 0.05 \\
Labour \& equipment & 1.58603 & 2.770507 & 0.00013 & 0.05 \\
Contractual & & & & \\
External & 1.74783 & 2.722689 & 0.001793 & 0.05 \\
& & & & \\
\hline
\end{tabular}

Table 2 ANOVA Results of each group for degree of frequency

\begin{tabular}{|c|c|c|c|c|}
\hline \multicolumn{5}{|c|}{ Degree of frequency } \\
\hline Groups & Fcritical & $\mathrm{F}$ & $\mathrm{P}$ value & $P$ sign \\
\hline Project & 1.58603 & 4.002597 & $3.25 \mathrm{e}-07$ & 0.05 \\
\hline Owner & 1.477814 & 4.64412 & $7.82 \mathrm{e}-13$ & 0.05 \\
\hline Contractor & 1.488708 & 4.924462 & $1.5 e-19$ & 0.05 \\
\hline
\end{tabular}




\section{Journal of Civil Engineering, Science and Technology}

Volume 9, Issue 1, April 2018

\begin{tabular}{lccll}
\hline Consultant & 1.58603 & 4.600519 & $2.23 \mathrm{e}-08$ & 0.05 \\
Design & 1.53208 & 5.900196 & $5 \mathrm{e}-13$ & 0.05 \\
Material & 1.58603 & 2.889076 & $7.15 \mathrm{e}-05$ & 0.05 \\
Labour \& equipment & 1.58603 & 5.455102 & $6.31 \mathrm{e}-10$ & 0.05 \\
Contractual & 1.747838 & 2.722689 & 0.001793 & 0.05 \\
External & 1.747838 & 3.313747 & 0.000273 & 0.05 \\
\hline
\end{tabular}

As $\mathrm{P}-$ Value is less than 0.05 i.e. 5\% Level of significance and $\mathrm{F}$ critical value is less than $\mathrm{F}$ value for the delay groups based on degree of severity and frequency, hence we accept the alternative hypothesis and can conclude that there is a significant difference between the Identified Delay Group leading to delay in Execution of Construction Projects.

\subsection{RELATIVE IMPORTANCE INDEX AND RANKING OF CAUSES OF DELAYS}

As per the ANNOVA Results, relative importance index was determined for the various causes identified under delay group for Severity and frequency of occurrence and the causes were ranked in the decreasing order of their criticality

Table 3 Ranking of causes of delay

\begin{tabular}{|c|c|c|c|c|c|}
\hline S.no & Causes for Delay & $\begin{array}{l}\text { Severity } \\
\text { Index } \%\end{array}$ & $\begin{array}{l}\text { Frequency } \\
\text { Index } \%\end{array}$ & $\begin{array}{c}\text { Relative } \\
\text { Importance } \\
\text { index (R.I.I)\% }\end{array}$ & Rank \\
\hline 1 & Late in revising and approving design documents & $78.89 \%$ & $67.22 \%$ & $53.03 \%$ & 1 \\
\hline 2 & $\begin{array}{l}\text { Delay due to sub-contractor and shortage of } \\
\text { manpower }\end{array}$ & $71.67 \%$ & $71.67 \%$ & $51.36 \%$ & 2 \\
\hline 3 & $\begin{array}{l}\text { Unavailability of equipment \& Frequent equipment } \\
\text { breakdown }\end{array}$ & $72.22 \%$ & $66.67 \%$ & $48.15 \%$ & 3 \\
\hline 4 & Labour disputes and unqualified workforce. & $71.67 \%$ & $63.89 \%$ & $45.79 \%$ & 4 \\
\hline 5 & $\begin{array}{l}\text { Changes in material types and specifications } \\
\text { during construction }\end{array}$ & $67.22 \%$ & $67.78 \%$ & $45.56 \%$ & 5 \\
\hline 6 & $\begin{array}{l}\text { Poor communication and coordination by owner } \\
\text { and other parties }\end{array}$ & $69.44 \%$ & $65.56 \%$ & $45.53 \%$ & 6 \\
\hline 7 & $\begin{array}{l}\text { Delaying in delivering the site and progress } \\
\text { payment. }\end{array}$ & $70.56 \%$ & $64.44 \%$ & $45.47 \%$ & 7 \\
\hline 8 & $\begin{array}{l}\text { Changes in scope and government regulations and } \\
\text { laws }\end{array}$ & $73.33 \%$ & $61.11 \%$ & $44.81 \%$ & 8 \\
\hline 9 & $\begin{array}{l}\text { Frequent change of sub-contractors because of } \\
\text { their inefficient work. }\end{array}$ & $72.22 \%$ & $61.67 \%$ & $44.54 \%$ & 9 \\
\hline
\end{tabular}



laws.

12 Ineffective planning, scheduling and training personnel.

13 Shortage of construction materials and delay in material supply.

Inadequate contractor's work experience and difficulties in financing project.

Poor communication/coordination between consultant and other parties

Lack of adequate communication between the parties

Delay in approving major changes in the scope of work by consultant 


\section{Journal of Civil Engineering, Science and Technology}

Volume 9, Issue 1, April 2018

28 Delay in site mobilization.

29 Not using advanced engineering design software's

30

31

Type of project bidding and shorter contract duration.

32

Suspension of work by owner.

33

Type of construction contract (Turnkey, construction only).

$57.78 \%$

$62.22 \%$

$58.33 \%$

$55.00 \%$

$57.78 \%$

$31.78 \%$

31

$53.33 \%$

$51.11 \%$

$27.26 \%$

32

$49.44 \%$

$50.56 \%$

$25.00 \%$

33

Out of all the causes of delay revising and approving design documents is figuring top rank followed by delay due to sub-contractor and shortage of manpower, frequent breakdown of equipment is in the $2^{\text {nd }}$ and third position. Similarly the rank for all the remaining causes of delay is reflected in Table 3 .

Table 4 Extremely critical and very critical causes for each groups

\begin{tabular}{llcl}
\hline Cause of delay $\quad$ Details of delay & Importance & Sndex
\end{tabular}

Legal disputes between various Parties

$\mathrm{I} . \mathrm{I}=32.41 \%$

Extremely Critical

Delay due to project group

Type of project bidding and shorter contract duration

I.I $=31.779 \%$

Very Critical

Late in revising and approving design documents

$\mathrm{I} . \mathrm{I}=53.03 \%$

Extremely Critical

Delay due to client

Poor communication and coordination by owner and other parties

$\mathrm{I} . \mathrm{I}=45.53 \%$

Very Critical

Delay due to

Delay due to sub-contractor and shortage of manpower

$\mathrm{I} . \mathrm{I}=51.36 \%$

Extremely Critical

contractor

Frequent change of sub-contractors because of their inefficient work.

$\mathrm{I} . \mathrm{I}=44.54 \%$

Very Critical

Delays in survey and producing design documents.

$\mathrm{I} . \mathrm{I}=38.31 \%$

Extremely Critical

Delay due to

designer

Inadequate design-team experience.

I.I $=34.99 \%$

Very Critical 


\section{Journal of Civil Engineering, Science and Technology}

Volume 9, Issue 1, April 2018

Delay due to labour and equipments

Delay due to supplier groups

Delay due to consultant

Delay due to contractual work

Delay due to external groups
Unavailability of equipment \& Frequent equipment

breakdown

$\mathrm{I} . \mathrm{I}=48.15 \%$

Extremely Critical

Labor disputes and unqualified workforce.

$\mathrm{I} . \mathrm{I}=45.79 \%$

Very Critical

Changes in material types and specifications during construction

$\mathrm{I} . \mathrm{I}=45.56 \%$

Extremely Critical

Shortage of construction materials and delay in material supply.

I.I $=42.81 \%$

Very Critical

Poor communication/coordination between consultant and other parties.

$\mathrm{I} . \mathrm{I}=41.16 \%$

Extremely Critical

Delay in approving major changes in the scope of work by consultant.

$\mathrm{I} . \mathrm{I}=38.72 \%$

Very Critical

Major disputes \& negotiations

$\mathrm{I} . \mathrm{I}=44.07 \%$

Extremely Critical

$\mathrm{I} . \mathrm{I}=39.70 \%$

Very Critical

Lack of adequate communication between the parties.

Land acquisition and government regulations and laws.

$\mathrm{I} . \mathrm{I}=43.66 \%$

Extremely Critical

Lack of database and experience and periodic meeting among the parties.

Very Critical

\subsection{CONCLUSIONS}

Based on the calculations made delays due to various causes are identified by groups. Various ranks obtained in the study portray the causes for delay. Among all the causes for delay the top rank goes to 'late in revising and approving design documents', subsequently delay due to subcontractor, delay due to non availability of manpower, frequent breakdown of equipment, labour disputes and change in material specifications in last minute are occupying from second rank to fifth rank respectively. These issues in the construction projects can be resolved by paying some more attention. The extremely critical and very critical causes are filtered out for each groups based on their relative importance index(RII) value and their percentage is portrayed. It is observed that the extremely critical delays are occurring from the client side as well as contractor side. They are likely due to late in revising and approving design documents by the client group is showing highest percentage. Secondly the sub-contractor is facing the shortage of manpower while executing the works which occupies more than $50 \%$ of the total value. Other causes are also contributing significantly for delays in execution of projects are due to lack of expertise in labor skills and equipment breakdown etc. Hence the present delay analysis emphasizes on certain things to be focused to reduce the delays in execution of construction projects will leads increase the site productivity.

\section{REFERENCES}

[1] Arditi, D., and Robinson, M. A, 1999 Concurrent Delays in Construction Litigation. Journal of Cost Engineering, 37(7), 20-30, 


\title{
Journal of Civil Engineering, Science and Technology
}

\author{
Volume 9, Issue 1, April 2018
}

[2] Al-Momani, A.H, 2000., Construction delay: A quantitative analysis. International Journal of Project Management, 18(1), 51-59.

[3] Sambasivan M and Soon Y, 2007., Causes and effects of delays in Malaysian construction industry, International Journal of Project Management, 25 (5), 517-526.

[4] Alkass S, Mazerolle M., and Harris F, 2010.,Construction delay analysis techniques. Journal of Construction Management and Economics, 14(5)., 375-394,.

[5] Aradhana Rathod et al.2013., Delays In Residential Building Construction, International Journal of innovative Research and Development(IJIRD), 2(5).,ISSN NO 2278-0211.

[6] Siddesh K Pai, J.Raj Bharath, 2013.,Analysis Of Critical Causes Of Delays In Indian Infrastructure Projects, International Journal of Innovative Research And Development ISSN: 2278 - 0211. 2(3).,251-263.

[7] B.P. Sunjka and U. Jacob, Significant Causes and Effects of Project Delays in the Niger delta region, Nigeria, Saiie25 Proceedings, 9th - 11th of July 2013, Stellenbosch, South Africa,.

[8] Dr. A. W. Dhawale1, S.C.,2014., Tandale, Analysis of Critical Factors Affecting The Construction Projects in Pune Region, India. International Journal of Civil Engineering and Technology. 5(3), 209-216,.

[9] Prakash Rao, B. and *Joseph Camron Culas, 2014., Causes of Delays in Construction Projects - A Case Study. International Journal of Current Research 6(6), 7219-7222.

[10] T. Subramani , P S Sruthi , M.Kavitha, 2014.,Causes of Cost Overrun In Construction, IOSR Journal of Engineering (IOSRJEN) 4(6)., 1-7.

[11] Hassan Emam1, Peter Farrell and Mohamed Abdelaal, ,Causes of Delay on Infrastructure Projects in Qatar, University of Bolton, Bolton, Proceedings of 31st Annual ARCOM Conference, 7-9 September 2015, Lincoln, UK, Association of Researchers in Construction Management, 773-782.

[12] Divya.R, S.Ramya, Causes, Effects and Minimization of Delays in Construction Projects, National Conference on Research Advances in Communication, Computation, Electrical Science and Structures (NCRACCESS- 2015)., ISSN NO 2348-8352., 47-53

[13] Asish Ram, Dr. Pratheeba Paul, 2015., Study on Construction Sequence Delay for Road Infrastructure Projects, IOSR Journal of Mechanical and Civil Engineering (IOSR-JMCE), 12(2) Ver. VI, 15-21, .

[14] Yogita Honrao , Prof.D.B.Desai, 2015.,Study of Delay in Execution of Infrastructure Projects -Highway Construction, International Journal of Scientific and Research Publications, ISSN 2250- 3153, 5(6).,1-8.

[15] Salim S. Mulla, Ashish P. Waghmare, (2015) A Study of Factors Caused for Time \& Cost Overruns in Construction Project \& their Remedial Measures, Int. Journal of Engineering Research and Applications, ISSN : 2248-9622, 5(1), ( Part -6), .48-53.

[16] Dinesh Kumar R ,2016., Causes and Effects of Delays in Indian Construction Projects, International Research Journal of Engineering and Technology , e-ISSN: 2395 -0056 ., 3(4)., 1831-1837.

[17] Kartik Kalkani Shakil Malek, 2016., Analysing Causes of Delay in Construction Projects, International Journal for Innovative Research in Science \& Technology, ISSN NO 2349-6010, 2(12),.257-262.

[18] TsegayGebrehiwet.,HanbinLuo., 2017., Analysis of delay impact on construct project based on RII and Correlation coefficient: Empirical study., Vol.196., 366-374.

[19] Desalegn Disasa Daba, Dr. Jayeshkumar Pitroda .,2018, A Critical Literature Review on Main Cause of Delay in Construction Projects International Journal for Innovative Research in Science \& Technology, ISSN NO 23950056, 5(1), 612-615. 